\title{
Transcriptions and Phonetics
}

\section{Reconstructions}

The reconstructions of Nostratic, Afroasiatic, and Indo-Hittite follow those of the scholars upon whose work the relevent chapters are largely based. These are Allan Bomhard and John C. Kerns for Nostratic; Vladimir E. Orel and Olga V. Stolbova for Afroasiatic; and Thomas V. Gamkrelidze and Vjačeslav V. Ivanov for IndoHittite. Their reconstructions are similar but not identical. All use an apostrophe after stops p', t', k' to indicate emphatic, sometimes glottalic consonants. Their precise nature is unclear but they are neither voiced nor unvoiced. When quoting Bomhard and Kerns and Gamkriledze and Ivanov, I use a capital H to signal a "laryngeal" of uncertain precise quality, as they have been lost in all branches of Indo-Hittite (except Anatolian). $\mathrm{H}$ is not necessary for describing the super-family of Proto-Afroasiatic because distinct "laryngeals" >, ', h, h and h have been preserved in several of its families. The diacritic ${ }^{[\mathrm{h}]}$ after a stop indicates a phonetic not phonemic, or meaningful alternation.

\section{Egyptian}

The orthography used in Egyptian words is the standard one used by Anglo-American Egyptologists and in previous volumes of this series, the only exception being that the sign traditionally transcribed as $\mathrm{k}$ is written $\mathrm{q}$ in this volume. 
Whatever the exact sound of the 3 in Old and Middle Egyptian (3400-I600 BCE), it was used where Semitic names contained $\mathrm{r}, 1$, or even $\mathrm{n}$. This consonantal value was retained until the beginning of the New Kingdom. In Late Egyptian (spoken, I6oo700 BCE), it appears to have become an >aleph and later, like the Southern English r, it merely modified adjacent vowels. The Egyptian i corresponded to the Semitic >aleph and yōd. >Aleph is found in many languages and in nearly all Afroasiatic ones. It is a glottal stop before vowels, as in the Cockney "bo>l" and "bu>ə" (bottle and butter). The Egyptian 'ayin, which occurs in most Semitic languages, is a voiced or spoken >aleph. The Egyptian form seems to have been associated with the back vowels o and $\mathrm{u}$.

In early Egyptian, the sign w, written as a quail chick, may have originally had purely consonantal value. In Late Egyptian, the stage of the Egyptian spoken language that had most impact on Greek, it seems to have been frequently pronounced as a vowel, either o or $\mathrm{u}$. The Egyptian sign transcribed as $\mathrm{r}$ was more usually rendered as 1 in Semitic and Greek. In later Egyptian, as with the 3, it weakened to become a mere modifier of vowels.

The Egyptian and Semitic has pronounced as an emphatic h. It appears that the sign conventionally transcribed in Egyptian as $\mathrm{h}$ was originally a voiced g. In Middle and Late Egyptian, it was devoiced to become something approximating the Scottish ch in "loch." The sign transcribed as $\underline{\mathrm{h}}$ was pronounced as hy. In Middle and Late Egyptian, it was frequently confused with $\breve{s}$. $\breve{s}$ used to transcribe a sign that originally sounded something like h. It later was pronounced as sh or skh.

As mentioned above, q represents an emphatic k.

The letter $\underline{t}$ was probably originally pronounced as $t^{\mathrm{y}}$. Even in Middle Egyptian it was already being confused with t. Similarly, $\underline{\mathrm{d}}$ was frequently alternated with d. In Late Egyptian, voiced and unvoiced stops tended to merge. Thus, there was confusion among $\underline{\mathrm{t}}, \mathrm{t}, \underline{\mathrm{d}}$, and $\mathrm{d}$. 


\section{Egyptian Names}

Egyptian divine names are vocalized according to the most common Greek transcriptions, for example, Amon for $>$ Imn and Isis for St.

Royal names generally follow A. H. Gardiner's (I96I) version of the Greek names for well-known pharaohs, for instance, Ramesses.

\section{Coptic}

Most of the letters in the Coptic alphabet come from Greek and the same transcriptions are used. Six other letters derived from Demotic are transcribed as follows:

$\begin{array}{lll}u \stackrel{r}{s} & g h \mathrm{~h} & x j \\ 4 f & 2 h & \sigma \check{c}\end{array}$

\section{Semitic}

The Semitic consonants are transcribed relatively conventionally. Several of the complications have been mentioned above in connection with Egyption. Apart from these, one encounters the following.

In Canaanite, the sound h merged with h. Transcriptions here sometimes reflect an etymological $\mathrm{h}$ rather than the later $\mathrm{h} . \mathrm{t}$ is an emphatic t. The Arabic letter $t h \bar{a}$ ' usually transcribed as th is written here as $\mathrm{t}^{\mathrm{y}}$. The same is true of the $d h \bar{a} l$, which is written here as $\mathrm{d}^{\mathrm{y}}$. The letter found in Ugaritic that corresponds to the Arabic ghain is transcribed as g.

The West Semitic tsade was almost certainly pronounced ts and the letter śin originally seems to have been a lateral fricative similar to the Welsh ll. In transcriptions of Hebrew from the First Millennium BCE the letter shin is rendered š. Elsewhere, it is transcribed simply as $s$ because I question the antiquity and range of the pronunciation š. 
Neither the dagesh nor begadkephat are indicated in the transcription. This is for reasons of simplicity as well as because of doubts about their range and occurrence in antiquity.

\section{Vocalization}

The Masoretic vocalization of the Bible, completed in the ninth and tenth centuries $\mathrm{CE}$ but reflecting much older pronunciation, is transcribed as follows:

\begin{tabular}{|c|c|c|c|c|}
\hline Name of sign & Plain & with' $y$ & with 1 w & with ה h \\
\hline Patah & 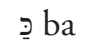 & - & - & -- \\
\hline Qåmes. & 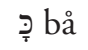 & פַּ bâ & - & bån båh \\
\hline Hîreq & bi bi & bî̀ bị & - & -- \\
\hline Șèrê & כִ bē & bê & - & bēh \\
\hline Segōl & כֶ be & ḅִ̂ bệ & - & לֶֶּ beh \\
\hline Hōlem & כ bō & -- & ỉ bô & כּן bōh \\
\hline Qibîs & כֶ bu & -- & bû כו bû & -- \\
\hline
\end{tabular}

The reduced vowels are rendered:

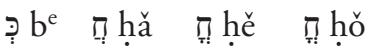

Accentuation and cantillation are not normally marked.

\section{Greek}

With some hesitation I have privileged the Greek alphabet over the Hebrew (Aramaic) and Egyptian hieroglyphs by retaining it whenever a new term is introduced, while transliterating all other scripts. The reason for this is that Egyptologists and Semitists as well as many lay users of the Roman alphabet find the Greek alphabet easy to read. By contrast, relatively few classicists can read Hebrew and virtually none, hieroglyphics. Determinatives are included when they can provide information not available from the transcription. 
The transcriptions of the consonants is orthodox. The same is true of the vowels $\eta$ and $\omega$, which are written as /ē/ and /ō/. Long $\bar{\alpha}$ is rendered $/ \bar{a} / . \Upsilon$ is conventionally transcribed as $/ y /$ despite the fact that nearly all the borrowings mentioned in these volumes took place before $v / u /$ was fronted to become /ü/. Some Semitic loans into Greek may be later as the same shift took place in Phoencian. Nevertheless, the most regular correspondences with the Greek $v$ were with earlier Semitic and Hebrew /u/ or Egyptian /w/. 
